\title{
Physiological and sanitary quality of maize seeds preconditioned in ozonated water
}

\author{
Christian V. Maximiano ${ }^{1}$, Ricardo Carmona ${ }^{1}$, Nara O. S. Souza ${ }^{1}$, Ernandes R. de Alencar ${ }^{1}$ \& Luiz E. B. Blum ${ }^{2}$ \\ ${ }^{1}$ Universidade de Brasília/Faculdade de Agronomia e Medicina Veterinária/Programa de Pós-Graduação em Agronomia. Brasília, DF. E-mail: \\ christianviter@hotmail.com - ORCID: 0000-0003-2020-9453; rcarmona@unb.br - ORCID: 0000-0001-7699-0387; narasouza@unb.br - ORCID: \\ 0000-0003-3221-7805; ernandesalencar@unb.br (Corresponding author) - ORCID: 0000-0003-4288-4097 \\ ${ }^{2}$ Universidade de Brasília/Departamento de Fitopatologia/Programa de Pós-Graduação em Agronomia. Brasília, DF. E-mail: luizblum@unb.br - ORCID: \\ 0000-0002-3968-6615
}

\section{Key words: \\ Zea mays \\ ozonation \\ health \\ conditioning}

\begin{abstract}
A B S T R A C T
The technique of controlled hydration of seeds has been used as a method of physiological conditioning to improve their performance in the field. Solution aeration with ozone gas is a promising option in controlling phytopathogens. The objective of the present study was to evaluate the physiological and sanitary quality of maize seeds preconditioned in ozonated water. In the evaluation of the physiological and sanitary quality, maize seeds were submitted to four concentrations of ozone gas $\left(0,10,20\right.$ and $\left.30 \mathrm{mg} \mathrm{L}^{-1}\right)$ for five soaking periods $(0$, 30, 60, 90 and $120 \mathrm{~min}$ ), with four replicates. Preconditioning maize seeds in ozonated water, followed by natural drying, resulted in a more pronounced initial development of seedlings, measured by means of the emergence speed index, seedling dry matter, seedling length and radicle length, compared with untreated seeds. The initial development of maize seedlings was intensified by the exposure of seeds to water, especially at 0 and $30 \mathrm{mg} \mathrm{L}^{-1}$ ozone concentrations during the period from 60 to $90 \mathrm{~min}$. Preconditioning maize seeds in ozonated water did not affect the control of Fusarium sp. The fungicide Carbendazim + Thiram resulted in $100 \%$ control of Fusarium sp. in the seeds.
\end{abstract}

\section{Palavras-chave: \\ Zea mays \\ ozonização \\ sanidade \\ condicionamento}

\section{Qualidade fisiológica e sanitária de sementes de milho pré-condicionadas em água ozonizada}

\section{R E S U M O}

A técnica de hidratação controlada das sementes vem sendo utilizada como método de condicionamento fisiológico, objetivando melhorar o seu desempenho no campo. A aeração da solução com gás ozônio constitui opção promissora no controle de fitopatógenos. $\mathrm{O}$ objetivo do presente trabalho foi estudar a qualidade fisiológica e sanitária de sementes de milho pré-condicionada em água ozonizada. Na avaliação da qualidade fisiológica e sanitária, as sementes de milho foram submetidas a quatro concentrações de gás ozônio $\left(0,10,20\right.$ e $\left.30 \mathrm{mg} \mathrm{L}^{-1}\right)$ em cinco períodos de embebição (0, 30, 60, 90 e $120 \mathrm{~min}$ ), com quatro repetições. A técnica de pré-condicionamento das sementes de milho em água ozonizada, seguida de secagem natural, acarretou desenvolvimento inicial mais acentuado das plântulas de milho, avaliado por meio do índice de velocidade de emergência, matéria seca de plântulas, comprimento de plântula e radícula, quando comparadas com as sementes não tratadas. $\mathrm{O}$ desenvolvimento inicial das plântulas de milho foi intensificado mediante exposição das sementes à água, especialmente nas concentrações de 0 e $30 \mathrm{mg} \mathrm{L}^{-1}$ de ozônio, durante o período de 60 a 90 min. O pré-condicionamento das sementes de milho em água ozonizada não afetou o controle de Fusarium sp. O fungicida carbendazim+thiram resultou em 100\% de controle de Fusarium sp. nas sementes. 


\section{INTRODUCTION}

Physiological conditioning is a technique of controlled hydration of seeds, which allows the activation of the metabolic processes of germination and avoids primary root production, favoring uniformization and better performance of the plants in the field (MacDonald \& Lada, 2009). This technique allows the use of reserves and synthesis of metabolites necessary to germination, leading to faster seed germination, reducing the time of exposure to unfavorable conditions, such as attacks by microorganisms and water deficit, among others (Marcos Filho, 2015).

Seed sanitary quality is fundamental, because contaminated seeds may reduce plant population and yield, and also serve as a vehicle for the spread of pathogens. Many fungi carried by maize seeds can be transmitted to the seedlings (Reis et al., 2004). The practice of using fungicides to treat maize seeds has still been the most employed by farmers. However, new technologies have been adopted in the control of fungi in grains, such as the use of ozone gas (Alencar et al., 2012; Rodrigues et al., 2015; Sanchez et al., 2016; Santos et al., 2016).

Ozone dissolved in water is a promising option in the control of microorganisms, being relatively unstable and easily decomposing into the form of molecular oxygen (Khadre et al., 2001). The use of new technologies, such as the preconditioning of seeds in ozonated water, can influence a series of characteristics important for seedling establishment, through the acceleration of seedling initial development and control of phytopathogens, such as Fusarium, which cause large losses in the initial establishment of the maize crop. In this context, the objective of the present study is to evaluate the physiological and sanitary quality of maize seeds preconditioned in ozonated water.

\section{Material ANd Methods}

The study was carried out with maize seeds, hybrid P30F53 (Pioneer Dupont), with 13\% water content (w.b.), at the Laboratories of Agricultural Products Processing and Seed Technology and at the Água Limpa Farm, of the Faculty of Agronomy and Veterinary Medicine, and at the Laboratory of Mycology, of the Phytopathology Department, all located at the University of Brasília, Brasília, DF, Brazil (154 45' 38 86" S; 47 52' $2694^{\prime \prime} \mathrm{W}$ ).

In the ozone generation process, oxygen $\left(\mathrm{O}_{2}\right)$ was used as input, with $90 \%$ purity, free from moisture, obtained from the $\mathrm{O}_{2}$ concentrator attached to the ozone generator. Ozone concentration was determined by the iodometric method (Clescerl et al., 1999). Ozone was injected in $800 \mathrm{~mL}$ glass container with lid, containing $140 \mathrm{~g}$ of maize seeds and $300 \mathrm{~mL}$ of distilled water, with electrical conductivity of $2.0 \mu \mathrm{S} \mathrm{cm}^{-1}$. The glass containers had lids with connections for gas injection and exhaustion. Four ozone gas concentrations in the water were tested: $0,10,20$ and $30 \mathrm{mg} \mathrm{L}^{-1}$, with flow rate of $1.0 \mathrm{~L} \mathrm{~min}^{-1}$, for the exposure of the seeds along five soaking periods: 0 , 30, 60, 90 and $120 \mathrm{~min}$. The ozone concentration of $0 \mathrm{mg} \mathrm{L}^{-1}$ (control) consisted in the injection of atmospheric air using an air compressor, at flow rate of $1.0 \mathrm{~L} \mathrm{~min}^{-1}$. After exposure to ozonated water, the seeds were dried at room temperature $(25 \pm$ $3{ }^{\circ} \mathrm{C}$ ) and relative humidity of $50 \pm 10 \%$, for $24 \mathrm{~h}$. Immediately after, physiological and sanitary quality tests were conducted.

To evaluate the effect of preconditioning of maize seeds in ozonated water on seed physiological quality, germination test (GT) was conducted and the following variables were determined: seedling length (SL), radicle length (RL), seedling dry matter (SDM), electrical conductivity (EC) and emergence speed index (ESI). The germination test was conducted in four replicates of 50 seeds, in a roll of Germitest paper at 25 ${ }^{\circ} \mathrm{C}$ (Brasil, 2009). Seedling and radicle lengths were measured in normal seedlings from the germination test, after seven days of its installation (Vieira \& Carvalho, 1994). Seedling dry matter was determined in normal seedlings from the GT, subsequently dried in oven at $80^{\circ} \mathrm{C}$ for $24 \mathrm{~h}$ (Nakagawa, 1994). To measure electrical conductivity, 50 seeds were previously weighed, immersed in $75 \mathrm{~mL}$ of deionized water and maintained at $25^{\circ} \mathrm{C}$ for $24 \mathrm{~h}$, in duplicate for each replicate. Solution electrical conductivity was read in a conductivity meter (Digimed), and the results were expressed in $\mu \mathrm{cm}^{-1} \mathrm{~g}^{-1}$ of seeds (Vieira \& Carvalho, 1994). To obtain the emergence speed index, manual sowing was performed in the field, with four replicates of 50 seeds for each combination of ozone concentration and soaking period. The number of emerged seedlings was daily counted, up to the $14^{\text {th }}$ day after sowing. At the end of this period, the ESI was calculated according to Maguire (1962).

In the evaluation of the effects of ozonated water on maize seed health, Fusarium sp. was initially isolated from maize seeds with symptoms. The fungus was grown in potato-dextrose-agar (PDA) medium and conserved in test tubes containing distilled water. Fusarium sp. inoculum was multiplied on plates with PDA, incubated at $25 \pm 3{ }^{\circ} \mathrm{C}$, with $12 \mathrm{~h}$ photoperiod. Plates with the fungus remained at $25 \pm 3{ }^{\circ} \mathrm{C}$ for 7 days. The seeds were previously disinfested in sodium hypochlorite (1\%) for $1 \mathrm{~min}$ and inoculated with Fusarium sp., through immersion in spore suspension $\left(10^{6}\right.$ conidia $\left.\mathrm{mL}^{-1}\right)$, for $10 \mathrm{~min}$, and then dried at $25 \pm 3^{\circ} \mathrm{C}$ for $24 \mathrm{~h}$ (Michel \& Radcliffe, 1995). After that, inoculated seeds were exposed to ozonated water, adopting different combinations of gas concentrations and soaking periods.

Health test was conducted using the filter paper method with freezing (Limonard, 1966). One hundred disinfested seeds (four replicates of 25) were used and later inoculated with Fusarium sp. The following controls were added to the treatments: untreated seeds with and without inoculation; seeds inoculated and treated with Carbendazim+Thiram (Derosal Plus: Carbendazim $150 \mathrm{~g} \mathrm{~L}^{-1}$, Thiram $350 \mathrm{~g} \mathrm{~L}^{-1} ; 200 \mathrm{~mL}$ c.p. $100 \mathrm{~kg}^{-1}$ seed); and inoculated seeds treated with $1 \%$ sodium hypochlorite for $1 \mathrm{~min}$. After the treatments, the seeds were placed in 'Gerbox' acrylic boxes (11 x 11 x $3.5 \mathrm{~cm})$, on two sheets of filter paper, previously moistened with distilled water and taken to the incubation chamber for $24 \mathrm{~h}\left(20 \pm 2^{\circ} \mathrm{C}\right)$, under daily regime of $12 \mathrm{~h}$ of white light. After this period, the seeds were placed in a freezer $\left(-20^{\circ} \mathrm{C}\right)$ for $24 \mathrm{~h}$ and then transferred to an incubation chamber for five days. After the incubation period, visual analyses were carried out to verify the presence or absence of fungal colonies in development. The results were expressed in percentage of infected seeds (Lucca Filho, 1987). 
The experimental design was completely randomized, in $4 \times 5$ factorial scheme, with four ozone concentrations $(0,10$, 20 and $\left.30 \mathrm{mg} \mathrm{L}^{-1}\right)$ and five soaking periods $(0,30,60,90$ and $120 \mathrm{~min}$ ), with four replicates. The data were initially subjected to analysis of variance. Means were compared by Tukey test at 0.05 probability level. Statistical analyses were performed in the program Assistat 7.5 (Silva \& Azevedo, 2009). After the analysis of variance, response surfaces of the characteristics as a function ozone concentrations and soaking periods were fitted, for the tests of seed physiological quality. For the health test, means were compared by Tukey test at 0.05 probability level. The program SigmaPlot version 10.0 (SYSTAT, 2006) was used for data graphical representation.

\section{Results AND Discussion}

Pre-soaking in ozonated water had significant effect on several physiological quality variables of maize seeds. Seedling length (SL), radicle length (RL), electrical conductivity (EC),

A.

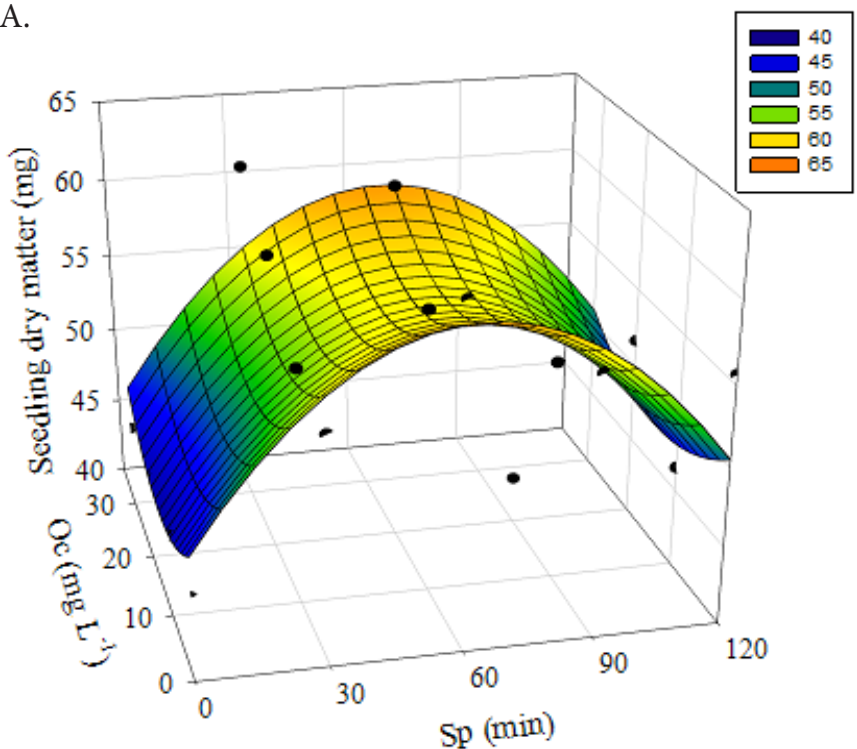

C.

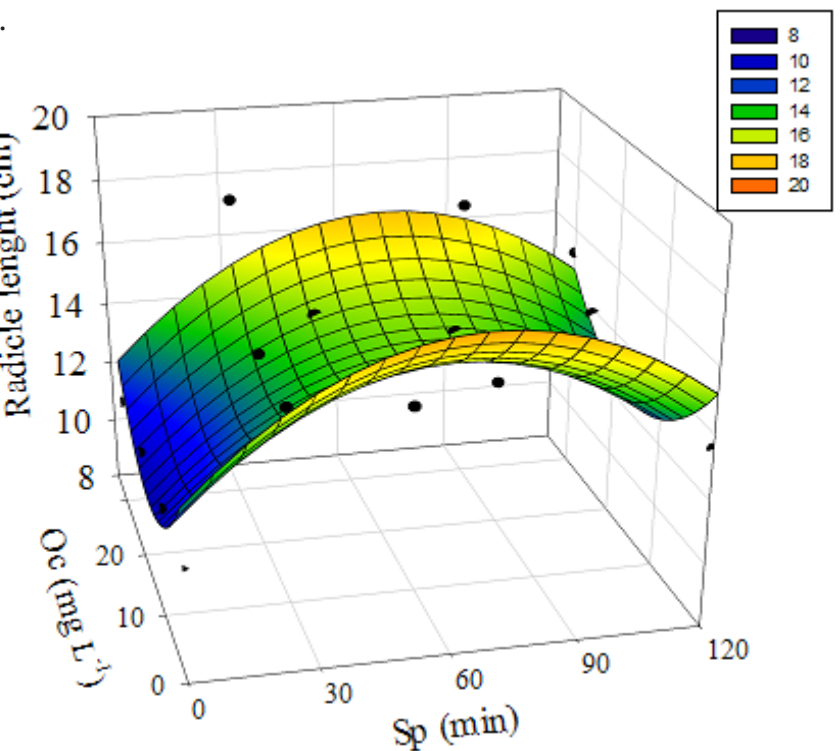

seedling dry matter (SDM), emergence speed index (ESI) and germination test $(\mathrm{GT})$ were significantly affected $(\mathrm{p}<0.05)$ by the interaction between ozone concentration and time of seed exposure to this substance.

The germination percentage of maize seeds subjected or not to ozonation in different combinations of ozone concentration and soaking periods remained with values above the standard required for commercialization, which is $85 \%$ (Brasil, 2013). Pre-soaking had no effect on seed germination rate. This trend is similar to the results of Oliveira \& Gomes Filho (2010), with sorghum seeds, in which the osmoconditioning did not influence germination, but promoted benefits to seed vigor.

On the other hand, preconditioning of maize seeds in ozonated or aerated water, followed by natural drying, accelerated the initial development of the seedlings. Such development was measured by the ESI, SDM, SL and RL. For all these variables, the maximum value, calculated by deriving the regression equation of the respective response surfaces (Figure 1 and Table 1), when maize seeds were pre-soaked in

B.

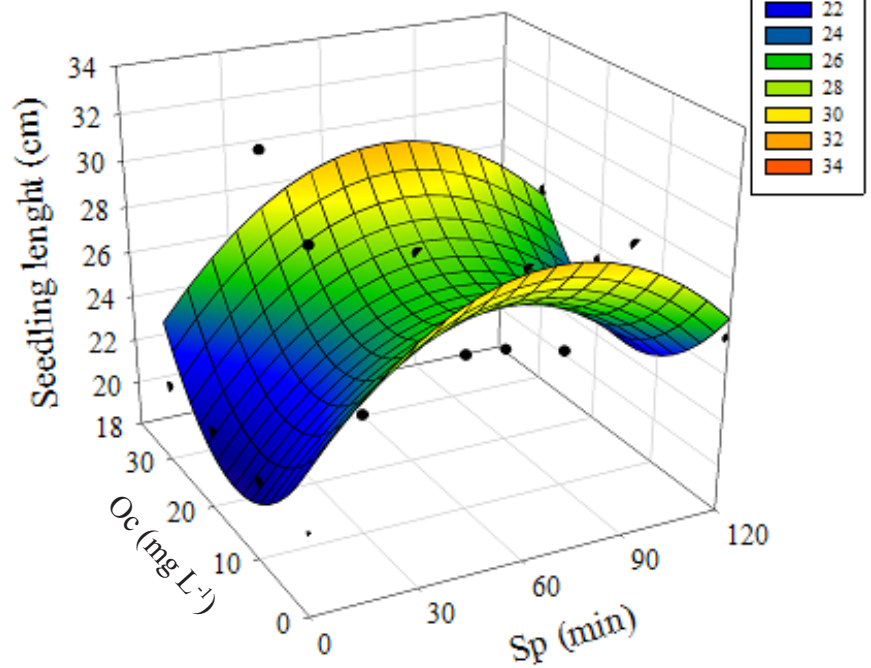

D.

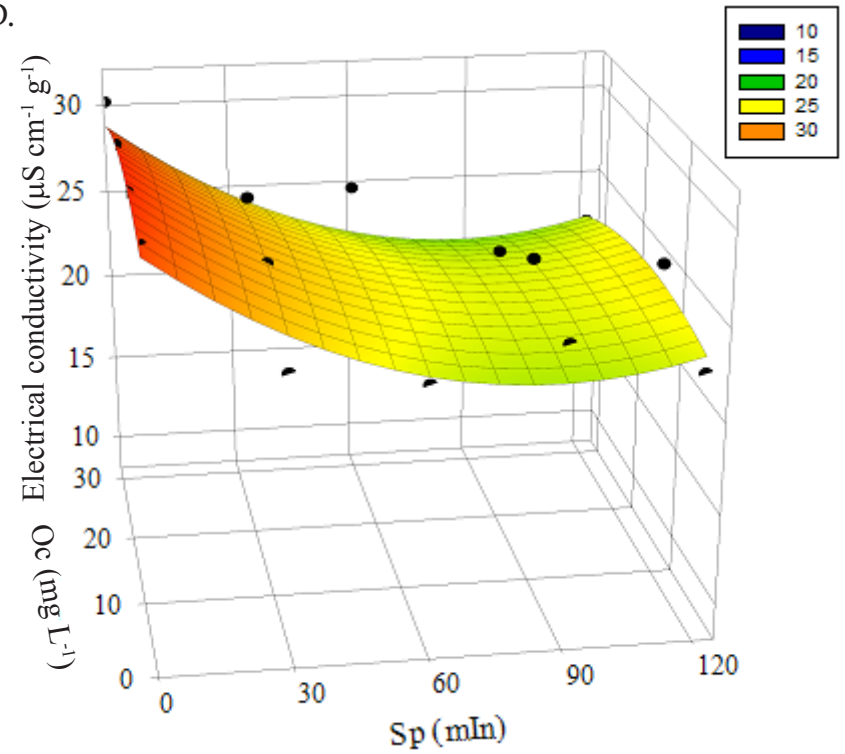

Figure 1. Response surfaces of seedling dry matter - SDM (A), seedling length - SL (B), radicle length - RL (C) and electrical conductivity - EC (D), as a function of the ozone concentration (Oc) and soaking period (Sp) of maize seeds in ozonated water 
Table 1. Fitted regression equations and the respective coefficients of determination $\left(r^{2}\right)$ of the response surfaces for emergence speed index (ESI), seedling dry matter (SDM), seedling length (SL), radicle length (RL) and electrical conductivity (EC) as a function of ozone concentration (Oc) and soaking period (Sp)

\begin{tabular}{|c|c|c|}
\hline Variable & Fitted equations & $\overline{R^{2}}$ \\
\hline ESI & $\mathrm{ESI}=6.234+0.030 \mathrm{Sp}^{*}-0.08150 \mathrm{c}^{*}-0.002 \mathrm{Sp}^{2^{*}}+0.0020 \mathrm{c}^{2 \mathrm{nS}}$ & 0.55 \\
\hline SDM & $\mathrm{SDM}=47.828+0.380 \mathrm{Sp}^{*}-0.3870 \mathrm{c}^{\mathrm{ns}}-0.003 \mathrm{Sp}^{2^{*}}+0.0130 \mathrm{c}^{2 \mathrm{~ns}}$ & 0.60 \\
\hline SL & $S L=23.918+0.180 S p^{\star}-0.5270 c^{*}-0.001 S p^{2^{\star}}+0.0180 c^{2^{\star}}$ & 0.67 \\
\hline$R L$ & $R L=13.343+0.123 S^{*}-0.3550 c^{*}-0.001 S p^{2^{*}}+0.0110 c^{2^{*}}$ & 0.70 \\
\hline $\mathrm{EC}$ & $\mathrm{EC}=30.068+0.1410 \mathrm{c}^{\mathrm{ns}}-0.171 \mathrm{Sp}^{*}-0.0060 \mathrm{c}^{2 \mathrm{~ns}}+0.001 \mathrm{Sp}^{2^{*}}$ & 0.78 \\
\hline
\end{tabular}

* Significant at $p \leq 5 \%$ (F test), ${ }^{\text {ns }}$ Not significant at $p \leq 5 \%$ (F test)

water at ozone concentrations of 0 and $30 \mathrm{mg} \mathrm{L}^{-1}$, during the soaking periods, were equal to $75 \mathrm{~min}$ for ESI; $63 \mathrm{~min}$ for SDM; $90 \mathrm{~min}$ for SL and $62 \mathrm{~min}$ for RL.

Although this technique had been initially proposed for vegetable seeds, some studies have demonstrated beneficial effects of osmoconditioning on seed germination and initial development of seedlings of other important crops under ideal or adverse conditions, as observed by Murungu et al. (2005) in maize and cotton.

According to Trigo \& Trigo (1999), when seeds are preconditioned in water or in osmotic medium, cell repair mechanisms that may contribute to restructuring the membrane system and reorganizing cell structural components are activated. These processes are evidences of possible reversibility in seed deterioration. Pre-soaking of seeds in aerated or ozonated water may have induced metabolic initiation through seed hydration, leading to improvement in the initial performance of the seedlings regarding emergence speed index, seedling dry matter (Figure 1A), seedling length (Figure 1B) and radicle length (Figure 1C). Controlled presoaking of seeds does not allow, for most species, the beginning of cell division and expansion, but can induce a prolonged capacity for synthesis of proteins, which promotes a more favorable metabolic balance, generating increments not in germination, but in seedling growth and biomass accumulation (Trigo \& Trigo, 1999).

Injection of atmospheric air or ozone in the water was probably an important factor to stimulate the initial development of the seedlings. For Parera \& Cantliffe (1994), the response to aeration during the conditioning varies according to species, and the ideal duration period of the treatment can be modified when an aeration system is used. It is important to highlight the satisfactory results of seedling development in the control treatment $\left(0 \mathrm{mg} \mathrm{L}^{-1}\right)$, which in this experiment were similar to those obtained at $30 \mathrm{mg} \mathrm{L}^{-1}$ ozone concentration. Probably, the injection of atmospheric air increased the concentration of oxygen dissolved in the water during the presoaking, which positively influenced seed physiological quality. Relatively long periods of immersion of seeds in water, with reduction in the oxygen content for embryo development, lead to changes from the normal aerobic pathway to the anaerobic pathway of ATP supply, with losses to the germination process (Franzin et al., 2007).

In seeds not subjected to pre-soaking in pure water or ozonated water, there were lower values of electrical conductivity (Figure 1D), around $30 \mu \mathrm{S} \mathrm{cm}^{-1} \mathrm{~g}^{-1}$. Pre-soaking period had a very evident effect on the electrical conductivity of maize seeds. Electrical conductivity decreased to approximately
$20 \mu \mathrm{S} \mathrm{cm}^{-1} \mathrm{~g}^{-1}$ when the seeds were pre-soaked in aerated or ozonated water, for up to $90 \mathrm{~min}$, followed by natural drying. This result suggests a possible beneficial effect of the presoaking process on the cell membrane integrity of the seeds, since the higher the organization level of the membranes, the lower the movement of solutes from the inside to the outside of the cells, reducing the electrical conductivity of the solution.

According to Taiz \& Zeiger (2004), the membrane is the first cell structure to suffer the action of soaking in water, and this structure depends on the presence of water to maintain the hydrophobic/hydrophilic orientation. Many studies report the benefits of preconditioning on seed physiological quality. Giurizzato et al. (2008) observed lower leaching of electrolytes in soybean seeds subjected to preconditioning in water, compared with seeds not preconditioned.

Fusarium sp. incidence percentage was equal to $100 \%$ in maize seeds inoculated and those not inoculated in the control treatment (Table 2). The treatment of inoculated seeds with sodium hypochlorite (1\%) for $1 \mathrm{~min}$ had positive effect on the control of Fusarium sp. in comparison to the control without treatment, but this fungus still developed in $70 \%$ of the seeds after treatment with hypochlorite. The treatment of inoculated seeds with the fungicide Carbendazim+Thiram was efficient to control Fusarium sp., resulting in almost $100 \%$ control of

Table 2. Mean percentage of maize seeds infected by Fusarium sp. as a function of the exposure to different combinations of ozone concentrations (Oc) and soaking periods (Sp) in water

\begin{tabular}{lcccc}
\hline Treatments & Inoculation & $\begin{array}{c}\text { Oc } \\
\left(\mathbf{m g ~ L}^{-1}\right)\end{array}$ & $\begin{array}{c}\text { Sp } \\
(\mathbf{m i n})\end{array}$ & $\begin{array}{c}\text { Incidence } \\
\text { of Fusarium (\%) }\end{array}$ \\
Control & No & - & - & $100.00 \mathrm{a}$ \\
Control & Yes & - & - & $100.00 \mathrm{a}$ \\
Fungicide & Yes & - & - & $0.01 \mathrm{c}$ \\
Hypochlorite & Yes & - & - & $70.00 \mathrm{~b}$ \\
& Yes & 0 & 30 & $100.00 \mathrm{a}$ \\
Aerated water & Yes & 0 & 60 & $100.00 \mathrm{a}$ \\
& Yes & 0 & 90 & $100.00 \mathrm{a}$ \\
& Yes & 0 & 120 & $100.00 \mathrm{a}$ \\
& Yes & 10 & 30 & $100.00 \mathrm{a}$ \\
& Yes & 10 & 60 & $100.00 \mathrm{a}$ \\
& Yes & 10 & 90 & $100.00 \mathrm{a}$ \\
& Yes & 10 & 120 & $100.00 \mathrm{a}$ \\
& Yes & 20 & 30 & $100.00 \mathrm{a}$ \\
& Yes & 20 & 60 & $100.00 \mathrm{a}$ \\
& Yes & 20 & 90 & $100.00 \mathrm{a}$ \\
& Yes & 20 & 120 & $100.00 \mathrm{a}$ \\
& Yes & 30 & 30 & $100.00 \mathrm{a}$ \\
& Yes & 30 & 60 & $100.00 \mathrm{a}$ \\
& Yes & 30 & 90 & $100.00 \mathrm{a}$ \\
& Yes & 30 & 120 & $100.00 \mathrm{a}$ \\
\hline
\end{tabular}

Means followed by the same letter in the columns do not differ statistically by Tukey test at 0.05 probability level 
the fungus. Maize seed exposure to ozonated water, at $30 \mathrm{mg}$ $\mathrm{L}^{-1}$, for up to $120 \mathrm{~min}$, did not show any effect on the control of Fusarium sp. All seeds exposed to these treatments had the fungus Fusarium sp. when incubated under favorable conditions to its development.

The fact that all seeds preconditioned in ozonated water had high percentage of Fusarium sp. incidence shows the inefficiency of ozone to control this fungus under the conditions tested in the present experiment. The increase of moisture in the superficial layer of the seeds, due to presoaking, may even have favored the infection by Fusarium sp., because of the stimulus to the germination of spores. According to Brandão et al. (2016), moisture is indispensable for the germination of most fungal spores and for the penetration in the germination tube of the host, besides increasing seed susceptibility to certain pathogens, affecting the incidence and severity of the disease. On the other hand, many studies have shown that the ozone gas applied directly in the seeds, in the absence of water, reduces fungal population and the biological activity of a variety of mycotoxins, corresponding to an effective method to disinfest and disinfect grains and seeds (Sahab et al., 2013; Luo et al., 2014; Savi et al., 2014).

\section{Conclusions}

1. Soaking maize seeds in water at ozone concentration of up to $30 \mathrm{mg} \mathrm{L}^{-1}$ for a period of up to $120 \mathrm{~min}$ does not affect germination when it is naturally high and reduces the loss of cellular solutes.

2. The initial development of maize seedlings is intensified by seed exposure to water, especially at ozone concentrations of 0 and $30 \mathrm{mg} \mathrm{L}^{-1}$ for a period from 60 to $90 \mathrm{~min}$.

3. Exposure of maize seeds to water with ozone concentration of up to $30 \mathrm{mg} \mathrm{L}^{-1}$ for up to $120 \mathrm{~min}$ is not efficient to control the fungus Fusarium sp.

\section{Literature Cited}

Alencar, E. R. de; Faroni, L. R. D.; Soares, N. de F. F.; Silva, W. A. da; Carvalho, M. C. da S. Efficacy of ozone as a fungicidal and detoxifying agent of aflatoxins in peanuts. Journal of the Science of Food and Agriculture, v.92, p.899-905, 2012. https://doi. org/10.1002/jsfa.4668

Brandão, F. J. B.; Biaggioni, M. A. M.; Sperotto, F. C. S.; Fujita, E; Santos, P. L.; Silva, M. A. P. da. Ozonated water in the postharvest treatment of coffee fruits. Revista Brasileira de Engenharia Agrícola e Ambiental, v.20, p.862-866. 2016. https://doi. org/10.1590/1807-1929/agriambi.v20n9p862-866

Brasil. Ministério da Agricultura, Pecuária e Abastecimento. Regras para análise de sementes. 1.ed. Brasília: MAPA/ACS, 2009. 395p.

Brasil. Ministério da Agricultura, Pecuária e Abastecimento. Instrução Normativa, $\mathrm{n}^{\circ}$ 45, de 17.09.2013. 2013.39p.

Clescer, L. S.; Greenberg, A. E.; Eaton, A. D. Standard methods for the examination of water and wastewater. 20.ed. Denver: American Water Works Association, 1999. 1325p.

Franzin, S. M.; Menezes, N. L. de; Garcia, D. C.; Tillmann, M. A. A. Pré-germinação de sementes de arroz de sequeiro. Revista Brasileira de Sementes, v.29, p.68-75, 2007. https://doi. org/10.1590/S0101-31222007000100010
Giurizzato, M. I. K.; Robaina, A. D.; Gonçalves, M. C.; Marchetti, M. E. Qualidade fisiológica de sementes de soja submetidas ao hidrocondicionamento. Acta Scientiarum. Agronomy, v.30, p.711-717, 2008. https://doi.org/10.4025/actasciagron.v30i5.5972

Khadre, M. A.; Yousef, A. E.; Kim, J.-G. Microbiological aspects of ozone applications in food: A review. Journal of Food Science, v.66, p.1242-1252, 2001. https://doi.org/10.1111/j.1365-2621.2001. tb15196.x

Limonard, T. A modified blotter test for seed health. Netherlands Journal of Plant Pathology, v.72, p.319-321, 1966. https://doi. org/10.1007/BF02650226

Lucca Filho, O. A. Testes de sanidade de sementes de milho. In: Soave, J.; Wetzel, M. M. V. da S. Patologia de sementes. Campinas: Fundação Cargill/Abrates, 1987. Cap.20, p.430-440.

Luo, X.; Wang, R.; Wang, L.; Li, Y.; Bian, Y. B.; Chen, Z. Effect of ozone treatment on aflatoxin $\mathrm{B}_{1}$ and safety evaluation of ozonized corn. Food Control, v.37, p.171-76, 2014. https://doi.org/10.1016/j. foodcont.2013.09.043

MacDonald, M. T.; Lada, R. R. Seed preconditioning with natural and synthetic antioxidants induces drought tolerance in tomato seedlings. HortScience, v.44, p.1323-1329, 2009.

Maguire, J. D. Speed of germination-aid in selection and evaluation for seedling emergence and vigor. Crop Science, v.2, p.176-177, 1962. https://doi.org/10.2135/cropsci1962.0011183X000200020033x

Marcos Filho, J. Fisiologia de sementes de plantas cultivadas. 2.ed. Londrina: Abrates, 2015. 659p.

Michel, B. E.; Radcliffe, D. A computer program relating solute potential to solution composition for five solutes. Agronomy Journal, v.87, p.126-130, 1995. https://doi.org/10.2134/agronj19 95.00021962008700010022x

Murungu, F. S.; Nyamugafata, P.; Chiduza, C.; Clark, L. J.; Whalley, W. R. Effects of seed priming and water potential on germination of cotton (Gossypium hirsutum L.) and maize (Zea mays L.) in laboratory assays. South African Journal of Plant and Soil, v.2, p.64-70, 2005. https://doi.org/10.1080/02571862.2005.10634683

Nakagawa, J. Testes de vigor baseados na avaliação das plântulas. In: Vieira, R. D.; Carvalho, N. M. Testes de vigor em sementes. Jaboticabal: FUNEP, 1994. p.49-85.

Oliveira, A. B. de; Gomes Filho, E. Efeito do condicionamento osmótico na germinação e vigor de sementes de sorgo com diferentes qualidades fisiológicas. Revista Brasileira de Sementes, v.32, p.25-34, 2010. https://doi.org/10.1590/S010131222010000300003

Parera, C. A.; Cantliffe, D. J. Presowing seed priming. Horticultural Reviews, v.16,p.109-139, 1994. https://doi.org/10.1002/9780470650561. ch4

Reis, E. M.; Casa, R. T.; Bresolin, A. C. R. Manual de diagnose e controle de doenças do milho. 2.ed. Lages: Graphel, 2004. 144p.

Rodrigues, V. O.; Costa, F. R.; Nery, M. C.; Cruz, S. M.; Melo, S. G. F. de; Carvalho, M. L. M. de. Treating sunflower seeds subjected to ozonization. Journal of Seed Science, v.37, p.202-210, 2015. https://doi.org/10.1590/2317-1545v37n3148582

Sahab, A. F.; Hassanien, F. R.; El-nemr, S. E.; Abdel-Alim, H. A.; AbdelWahhab, M. A. Effect of ozone gaseous on aflatoxin degradation and fat and protein content in peanut seeds. Journal of Applied Sciences Research, v.9, p.2170-2175, 2013. 
Sanchez, B. A. O.; Alencar, E. R. de; Pineli, L. de L. de O.; Ferreira, W. F. de S., Roberto, M. de A. Tracing interactions among column height, exposure time and gas concentration to dimension peanut antifungal ozonation. Food Science and Technology, v.65, p.668-675, 2016. https://doi.org/10.1590/1807-1929/agriambi.v20n3p230-235

Santos, R. R.; Faroni, L. R. D.; Cecon, P. R.; Ferreira, A. P. S.; Pereira, O. L. Ozone as fungicide in rice grains. Revista Brasileira de Engenharia Agrícola e Ambiental, v.20, p.230-235, 2016. https:// doi.org/10.1590/1807-1929/agriambi.v20n3p230-235

Savi, G. D.; Piacentini, K. C.; Bittencourt, K. O.; Scussel, V. M. Ozone treatment efficiency on Fusarium graminearum and deoxynivalenol degradation and its effects on whole wheat grains (Triticuma estivum L.) quality and germination. Journal of Stored Products Research, v.59, p.245-253, 2014. https://doi.org/10.1016/j.jspr.2014.03.008
Silva, F. A. S.; Azevedo, C. A. V. Principal components analysis in the software assistat-statistical assistance. In: World Congress on Computers in Agriculture, 7. 2009, Reno. Proceedings... St. Joseph: ASABE, 2009. CD-Rom

SYSTAT. SigmaPlot for Windows Version 10.0. San Jose: Systat Software Inc., 2006.

Taiz, L.; Zeiger, E. Fisiologia vegetal. 3.ed. Porto Alegre: Artmed, 2004. 719p.

Trigo, M. F. O. O.; Trigo, L. F. N. Efeito do condicionamento osmótico na germinação e no vigor de sementes de berinjela. Revista Brasileira de Sementes, v.21, p.107-113, 1999. https://doi. org/10.17801/0101-3122/rbs.v21n1p107-113

Vieira, R. D.; Carvalho, N. M. Testes de vigor em sementes. 1.ed. Jaboticabal: FUNEP, 1994, 164p. 